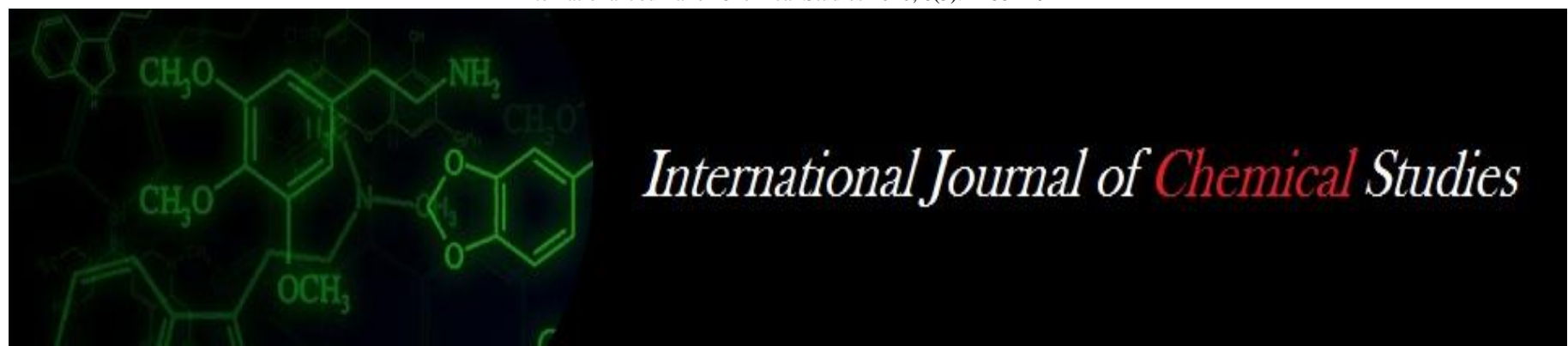

P-ISSN: 2349-8528

E-ISSN: 2321-4902

www.chemijournal.com

IJCS 2020; 8(5): 1188-1192

(C) 2020 IJCS

Received: 14-07-2020

Accepted: 21-08-2020

\section{Pravamanjari Giri}

Scientist, Agronomy, KVK,

Balasore, Balasore, Odisha, India

\section{Basudev Behera}

Professor, Agronomy, IAS,

SOADU, Bhubaneswar, Odisha, India

\section{Amit Mishra}

Assistant Professor, Department of Soil Science and Agricultural Chemistry, Banda University,

Meerut, Uttar Pradesh, India

Stuti Debapriya Behera

Ph.D. Scholar, Department of

Agronomy, OUAT,

Bhubaneswar, Odisha, India
Corresponding Author:

Pravamanjari Giri

Scientist, Agronomy, KVK,

Balasore, Balasore, Odisha, India

\section{Productivity, profitability, energetics and nutrient uptake of post $k$ harif rice-cowpea preceded by rice varieties grown under different establishment methods}

\author{
Pravamanjari Giri, Basudev Behera, Amit Mishra and Stuti Debapriya \\ Behera
}

DOI: https://doi.org/10.22271/chemi.2020.v8.i5q.10452

\begin{abstract}
A field experiment was conducted at Agronomy Main Research Farm, Department of Agronomy, College of Agriculture, OUAT, Bhubaneswar, Odisha during of 2014-15 and 2015-16 to evaluate the productivity, profitability, energetics and nutrient uptake of post kharif rice-cowpea preceded by rice varieties grown in kharif under different establishment methods. The treatments comprising three establishment methods(Direct Seeded Rice, Non Puddled Transplanted Rice and Puddled Transplanted rice) and three variety/hybrids of rice ('Arize 6129', 'Arize 6444' and 'Swarna') were tried in split plot design with three replications. The Puddled Transplanted Rice (PTR) recorded the maximum rice equivalent yield $\left(8.43 \mathrm{t} \mathrm{ha}^{-1}\right)$ for post kharif rice-cowpea which was at par with NPTR $\left(8.34 \mathrm{t} \mathrm{ha}^{-1}\right)$ and the minimum of $6.85 \mathrm{t} \mathrm{ha}^{-1}$ was recorded under Direct Seeded Rice (DSR). The total cowpea biomass yield was the maximum under NPTR and the minimum under DSR. The maximum gross return of ₹ $1,20,380 /-$, total energy output of 2,25,045 $\mathrm{MJ} \mathrm{ha}^{-1}$ and energy use efficiency of 8.59 was recorded under PTR, NPTR and DSR, respectively. Uptake of nitrogen was higher under NPTR while phosphorus and potassium uptake values were higher under PTR. The rice cultivar/hybrids grown in kharif had no significant effect on yield, economics, energetics and uptake of nutrient, but hybrid 'Arize 6129' recorded higher mean values than hybrid 'Arize 6444' and cv. 'Swarna'.
\end{abstract}

Keywords: DSR, NPTR, PTR, REY, economics, energetics, nutrient uptake, cowpea residue

\section{Introduction}

Cropping intensity of the Eastern India is as low as $140 \%$ in an irrigated ecosystem, which can be enhanced to $300 \%$ by adopting developed diversified cropping systems (Singh et al., 2012) [8]. Crop diversification has been recognized as an effective strategy for achieving the objectives of food security, nutrition security, income growth, poverty alleviation, employment generation and the judicious use of land and water resources, sustainable agriculture development and environmental improvement (Singh, 2010) ${ }^{[9]}$. Inclusion of legumes and other crops using intensification and interruptive approaches, as per resource availability, led to considerable improvement in productivity and profitability of the system and fertility of soil (Gangwar and Ram, 2005) ${ }^{[2]}$. Pulses provide an important option for diversification of conventional cereal-based rotations due to various inherent qualities like biological N-fixation, short duration, deep root, easy to accommodate under diverse agro-ecosystems and more importantly complementarity with cereals. The scope for exploiting direct and residual fertility due to legumes becomes increasingly apparent in India that has very low level of average plant nutrients consumption from chemical fertilizers on national basis (Ghosh et al. 2006) ${ }^{\text {[3] }}$. Sharma et al. (2005) ${ }^{[7]}$ reported that the cropping system with pulse crop significantly increases the grain yield in direct seeded rice as compared to transplanting method carried out for the rice crop. The implications of including pulses in cereal-based system were explored by various researchers in particular concerning soil quality, system productivity and sustainability. Introducing pulses in cereal based system may alter the input-output balance over cereal-cereal system. 


\section{Materials and methods}

The experiment was conducted at Agronomy Main Research Farm, Department of Agronomy, College of Agriculture, OUAT, Bhubaneswar, Odisha during of 2014-15 and 201516. The experimental site is located at Bhubaneswar, Odisha, India with latitude of $20^{\circ} 15^{\prime} \mathrm{N}$, longitude of $85^{\circ} 52^{\prime} \mathrm{E}$ and altitude of $25.9 \mathrm{~m}$ above mean sea level. The station falls under the East and South Eastern Coastal Plains Agroclimatic Zone of Odisha as per NARP classification (AZ 63) and Agro Ecological Sub Region (AESR) 18.4 of NBSS \& LUP classification. The total rainfall received during 2014-15 and 2015-16 was 1534 ans $994 \mathrm{~mm}$, respectively. The mean monthly minimum and the mean monthly maximum temperature recorded during $2014-15$ was $13.9^{\circ} \mathrm{C} \& 38.9^{\circ} \mathrm{C}$, respectively while during 2015-16 the mean monthly minimum and the mean monthly maximum temperature was $15.7^{\circ} \mathrm{C}$ and $40.8^{\circ} \mathrm{C}$, respectively. The relative humidity ranged from 85 to $95 \%$ in morning and 39 to $82 \%$ in evening during 2014-15 and 82 to $93 \%$ in morning and 36 to $77 \%$ in evening hours during 2015-16. The soil at the experimental site was sandy loam.

The experiment was laid out in split plot design with three crop establishment methods viz. direct seeded rice (DSR), non-puddled transplanted rice (NPTR) and puddled transplanted rice (PTR) allocated to main plots and three cultivar duration groups viz. short duration ('Arize 6129'), medium duration ('Arize 6444') and long duration ('Swarna') allotted to sub plotsin kharif season and treatments replicated thrice. After kharif rice, short duration rice cv. 'Arize 6129' and cowpea cv. 'Utkal Manik' were grown uniformly during rabi and summer, respectively, for productive utilisation of fallow period. The recommended fertilizer dose of 120-60-60$5 \mathrm{~kg} \mathrm{~N}-\mathrm{P}_{2} \mathrm{O}_{5}-\mathrm{K}_{2} \mathrm{O}-\mathrm{Zn} / \mathrm{ha}$ was applied to both kharif and rabi rice. No fertilizes was applied to the cowpea except $2 \%$ foliar spraying of DAP at flowering stage.The fertilizer amounting to $24 \mathrm{~kg} \mathrm{~N}$ and full dose of phosphorus, potash and zinc was applied as basal in the form of DAP, MOP and zinc sulphate before sowing in DSR and final cultivation in NPTR and PTR to rice. Then four top dressings of $\mathrm{N}$ were done at fortnight interval with $24 \mathrm{~kg} \mathrm{~N}$ per split applied in the form of urea starting at tillering stage and the last top dressing coinciding with the panicle initiation stage. The experimental field was initially dry ploughed with tractor drawn disc harrow followed by cultivator and rotavator operations to get fine tilth. Laser leveling was done to get perfect leveling. For preparing the field under Puddled Transplanted Rice (PTR), the ploughed field was given flooded irrigation. Then the field was puddled well with cage wheel and leveled with wooden leveling board. Under Non- Puddled Transplanted Rice (NPTR) field was initially dry ploughed with tractor drawn cultivator followed by rotavator to get fine tilth. Thereafter, the ploughed field was given a surface wetting with $50 \mathrm{~mm}$ of water which was just sufficient to soak the soil for smoother transplanting of seedling. In dry seeded rice (DSR), plots were initially dry ploughed with tractor drawn cultivator followed by rotavator to get fine tilth.

After rabi rice, cowpea was established as a zero till crop with spacing of $30 \mathrm{~cm} \times 15 \mathrm{~cm}$. Cowpea residue was incorporated after one picking under DSR plot and three number of pickings of fresh pod of cowpea under NPTR and PTR. Economic yields (pod yield) of cowpea was converted to riceequivalent yield (REY), taking into account the prevailing market price $(₹ / \mathrm{kg})$ of rice (13.60 in $2014-15$ and 14.10 in 2015-16) and cowpea (20.00/kg fresh pod). Gross returns of each crop establishment methods, cultivars and post kharif crops were calculated from sale price of grain (according to minimum support price declared by Government of India) and straw during their respective crop growing seasons. Net returns were calculated by subtracting cost of production from gross returns, whereas benefit-cost ratio $(\mathrm{B}: \mathrm{C})$ was calculated by dividing gross returns with cost of production.

Energy fluxes were estimated using crop management (machinery operations and amount of inputs used) and grain and by-products production records. Inputs and outputs were converted from physical to energy unit measures through published conversion coefficients (Table 1). Energy equivalents for all inputs were summed to provide an estimate of total energy inputs. Energy output from the economic yield (grain) and by-products was calculated by multiplying the amount of production by its corresponding energy equivalent. Net energy returns and energy use efficiency were calculated by using the following formulae as suggested by Mittal and Dhawan (1988) ${ }^{[4]}$.

1. Net energy return(MJ.ha-1 ${ }^{-1}=$ Total Output Energy (MJ.ha $\left.{ }^{1}\right)$ - Total Input Energy (MJ.ha' $\left.{ }^{-1}\right)$

2. Energy use efficiency $=$ Total Output Energy (MJ.ha $\left.{ }^{1}\right) /$ Total Input Energy (MJ.ha $\left.{ }^{-1}\right)$

3. The nutrient uptake was calculated by multiplying nutrient content in grain/pod and straw/stover with corresponding yield and expressed in $\mathrm{kg} \mathrm{ha}^{-1}$.

Table 1: Energy coefficient of inputs and outputs

\begin{tabular}{|c|c|}
\hline Component & Energy coefficient (MJunit ${ }^{-1}$ ) \\
\hline Labor $(\mathrm{hr})$ & 1.96 \\
\hline Diesel $(\mathrm{lt})$ & 56.31 \\
\hline Electricity $(\mathrm{kWh})$ & 11.93 \\
\hline Seed $(\mathrm{kg})$ & 14.7 \\
\hline $\mathrm{N}(\mathrm{kg})$ & 60.6 \\
\hline $\mathrm{P}_{2} \mathrm{O}_{5}(\mathrm{~kg})$ & 11.1 \\
\hline $\mathrm{K}_{2} \mathrm{O}(\mathrm{kg})$ & 6.7 \\
\hline $\mathrm{ZnSO}_{4}(\mathrm{~kg})$ & 20.9 \\
\hline Herbicide $(\mathrm{kg})$ & 288 \\
\hline Insecticide $(\mathrm{kg})$ & 237 \\
\hline Fungicide $(\mathrm{kg})$ & 196 \\
\hline Irrigation $(\mathrm{m} 3)$ & 1.02 \\
\hline Machinery $(\mathrm{hr})$ & 62.7 \\
\hline Rice grain $(\mathrm{kg})$ & 14.7 \\
\hline Rice straw $(\mathrm{kg})$ & 12.5 \\
\hline Cowpea pod $(\mathrm{kg})$ & 3.91 \\
\hline Cowpea stover $(\mathrm{kg})$ & 12.5 \\
\hline
\end{tabular}

\section{Results and discussion}

Rice equivalent yield of rice-cowpea and residue yield of cowpea

Establishment methods didn't influence grain yield of rice in rabi season significantly (Table 2). But PTR recorded the maximum $\left(6.30 \mathrm{t} \mathrm{ha}^{-1}\right)$ followed by NPTR $\left(6.18 \mathrm{t} \mathrm{ha}^{-1}\right)$ and $\operatorname{DSR}\left(6.01 \mathrm{tha}^{-1}\right)$. This result was consistent with findings of Alam et al., (2017) ${ }^{[1]}$. Rice crop establishment methods influenced cowpea pod yield significantly. The NPTR recorded the maximum pod yield $1.50 \mathrm{t} \mathrm{ha}^{-1}$ and PTR $(1.47 \mathrm{t}$ $\left.\mathrm{ha}^{-1}\right)$ was at par. The minimum pod yield was recorded under DSR $\left(0.58 \mathrm{t} \mathrm{ha}^{-1}\right)$ due to lesser time period occupied in field, which is attributed by sowing of cowpea in the same date under all the establishment methods due to excess soil moisture and only one picking under DSR to prepare the main field for direct seeding unlike seedling raising under NPTR and PTR. Thus the rice equivalent yield of cowpea followed the order of NPTR $>$ PTR $>$ DSR. Rice equivalent yield for post kharif rice-cowpea was computed by adding yield of rabi rice and rice equivalent yield of cowpea, which was 
significantly affected by different establishment methods. The PTR recorded the maximum rice equivalent yield of $8.43 \mathrm{t}$ ha ${ }^{1}$ which was at par with NPTR $\left(8.34 \mathrm{t} \mathrm{ha}^{-1}\right)$. The minimum rice equivalent yield was recorded under DSR (6.85 $\left.\mathrm{t} \mathrm{ha}^{-1}\right)$ which may be attributed to low pod yield of cowpea.

The amount of residues incorporated from cowpea following the cultivation of rice under different establishment methods differed significantly. The NPTR (3.64 t ha' $)$ registered the maximum residues for incorporation, while DSR recorded the minimum (3.31 $\left.\mathrm{t} \mathrm{ha}^{-1}\right)$. Cultivar duration failed to cause significant variation in yield of component crops, rice equivalent yields and cowpea residue for incorporation. However, 'Azize 6129' recorded higher values over 'Arize 6444' and 'Swarna'. Similar result was reported by Mukundam et al. (2012) ${ }^{[5]}$.

Table 2: Economic yield of rabi and summer crops, rice-equivalent yield (REY) and cowpea biomass yield as affected by establishment methods and cultivar duration of kharif rice

\begin{tabular}{|c|c|c|c|c|c|c|c|c|c|c|}
\hline \multirow[t]{2}{*}{ Particulars } & \multicolumn{2}{|c|}{$\begin{array}{c}\text { Grain yield of rabi rice } \\
\left(\mathrm{t} \mathrm{ha}^{-1}\right)\end{array}$} & \multicolumn{2}{|c|}{$\begin{array}{c}\text { Pod yield of cowpea } \\
\left(t_{\left.\text {ha }^{-1}\right)}\right.\end{array}$} & \multirow{2}{*}{\multicolumn{2}{|c|}{ 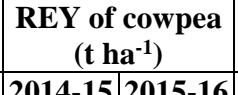 }} & \multicolumn{2}{|c|}{$\begin{array}{c}\text { REY of post kharif crops } \\
\left(\mathbf{t ~ h a}^{-1}\right)\end{array}$} & \multicolumn{2}{|c|}{$\begin{array}{c}\text { Cowpea biomass yield } \\
\qquad\left(\mathrm{t} \mathrm{ha}^{-1}\right)\end{array}$} \\
\hline & 2014-15 & 2015-16 & 2014-15 & $2015-16$ & & & 2014-15 & 2015-16 & 2014-15 & 2015-16 \\
\hline \multicolumn{11}{|c|}{ Establishment method } \\
\hline DSR & 6.04 & 5.97 & 0.58 & 0.58 & 0.85 & 0.82 & 6.89 & 6.80 & 3.30 & 3.31 \\
\hline NPTR & 6.17 & 6.19 & 1.47 & 1.53 & 2.16 & 2.16 & 8.33 & 8.35 & 3.63 & 3.64 \\
\hline PTR & 6.21 & 6.39 & 1.44 & 1.50 & 2.12 & 2.13 & 8.33 & 8.52 & 3.51 & 3.53 \\
\hline SEm \pm & 0.12 & 0.11 & 0.03 & 0.05 & 0.04 & 0.07 & 0.13 & 0.14 & 0.03 & 0.04 \\
\hline $\mathrm{CD}(\mathrm{P}=0.05)$ & NS & NS & 0.10 & 0.18 & 0.15 & 0.26 & 0.50 & 0.56 & 0.11 & 0.16 \\
\hline \multicolumn{11}{|c|}{ Cultivar duration } \\
\hline Arize 6129 & 6.11 & 6.26 & 1.19 & 1.24 & 1.75 & 1.76 & 7.86 & 8.01 & 3.51 & 3.53 \\
\hline Arize 6444 & 6.16 & 6.11 & 1.16 & 1.20 & 1.70 & 1.71 & 7.86 & 7.82 & 3.48 & 3.50 \\
\hline Swarna & 6.16 & 6.18 & 1.14 & 1.17 & 1.68 & 1.66 & 7.83 & 7.84 & 3.45 & 3.46 \\
\hline SEm \pm & 0.10 & 0.09 & 0.06 & 0.06 & 0.08 & 0.08 & 0.12 & 0.11 & 0.05 & 0.07 \\
\hline $\mathrm{CD}(\mathrm{P}=0.05)$ & NS & NS & NS & NS & NS & NS & NS & NS & NS & NS \\
\hline
\end{tabular}

\section{Economics}

Establishment methods influenced gross return of post kharif crops significantly (Table 3). The PTR recorded the maximum gross return of ₹1,20,380/- being at par with NPTR (₹ $1,19,405 /-)$ and the DSR recorded the minimum of $₹ 98,900 /$ - . Net return was not significantly influenced by establishment methods in the $1^{\text {st }}$ year. In the $2^{\text {nd }}$ year. The
PTR and the DSR gave the maximum(₹51,910/-) and minimum (₹40,900/-) net return, respectively, which contradicts the findings of Sarangi et al., (2020) ${ }^{[6]}$. Establishment methods failed to cause significant variation on benefit cost ratio. Higher $\mathrm{B}: \mathrm{C}$ was observed in the $2^{\text {nd }}$ year than the $1^{\text {st }}$ year. Cultivars did not exert significant influence on production economics of post kharif crops.

Table 3: Effect of crop establishment methods and cultivar duration of kharif rice on economics of post kharif rice - cowpea

\begin{tabular}{|c|c|c|c|c|c|c|}
\hline \multirow{2}{*}{ Particulars } & \multicolumn{2}{|c|}{ Gross return $\left(\times 10^{3} ₹ \mathrm{ha}^{-1}\right)$} & \multicolumn{2}{|c|}{ Net return $\left(\times 10^{3} ₹ h^{-1}\right)$} & \multicolumn{2}{|c|}{ B C ratio } \\
\hline & 2014-15 & $2015-16$ & 2014-15 & $2015-16$ & 2014-15 & $2015-16$ \\
\hline \multicolumn{7}{|c|}{ Establishment method } \\
\hline DSR & 97.87 & 99.93 & 40.08 & 40.90 & 1.69 & 1.69 \\
\hline NPTR & 116.97 & 121.84 & 47.49 & 51.13 & 1.68 & 1.72 \\
\hline PTR & 116.64 & 124.12 & 45.66 & 51.91 & 1.64 & 1.72 \\
\hline SEm \pm & 1.71 & 2.08 & 1.71 & 2.08 & 0.025 & 0.031 \\
\hline $\mathrm{CD}(\mathrm{P}=0.05)$ & 6.72 & 8.17 & NS & 8.17 & NS & NS \\
\hline \multicolumn{7}{|c|}{ Cultivar duration } \\
\hline Arize 6129 & 110.37 & 117.02 & 44.29 & 49.70 & 1.67 & 1.74 \\
\hline Arize 6444 & 110.91 & 114.30 & 44.83 & 46.99 & 1.68 & 1.69 \\
\hline Swarna & 110.20 & 114.57 & 44.11 & 47.25 & 1.67 & 1.70 \\
\hline SEm \pm & 1.74 & 1.60 & 1.74 & 1.60 & 0.026 & 0.025 \\
\hline $\mathrm{CD}(\mathrm{P}=0.05)$ & NS & NS & NS & NS & NS & $\mathrm{NS}$ \\
\hline
\end{tabular}

\section{Energetics}

Puddled transplanted rice $\left(33,070 \quad \mathrm{MJ}^{-1}\right)$ recorded significantly higher total energy input requirement by post kharif crops (Table 4) followed by NPTR (29,430 MJ ha-1) and DSR $\left(25,500 \mathrm{MJ} \mathrm{ha}^{-1}\right)$. The minimum requirement of energy input under DSR was mainly due to reduced number of tillage for the main field preparation and less irrigation water given to the crop. Establishment methods significantly influenced the total energy output of post kharif crops in the $1^{\text {st }}$ year. The NPTR recorded the maximum energy output $\left(2,25,200 \mathrm{MJ} \mathrm{ha}^{-1}\right)$ which was at par with PTR $(2,23,640 \mathrm{MJ}$ $\left.\mathrm{ha}^{-1}\right)$ and the minimum was recorded under DSR $(2,17,965$ MJ ha-1). Establishment methods exhibited the similar trend in the $2^{\text {nd }}$ year, but the differences were not statistically significant. During both the years, net energy return was not significantly influenced. But, the years exhibited differential trend for this parameter. In the $1^{\text {st }}$ year, the trend was NPTR $\left(1,95,650 \mathrm{MJ} \mathrm{ha}^{-1}\right)>\operatorname{DSR}\left(1,93,860 \mathrm{MJ} \mathrm{ha}^{-1}\right)>$ PTR $(1,90,580$ MJ ha-1), while in the $2^{\text {nd }}$ year, the trend was NPTR $(1,97,640$ MJ ha $\left.{ }^{-1}\right)>$ PTR $\left(1,93,390 \mathrm{MJ} \mathrm{ha}^{-1}\right)>\operatorname{DSR}\left(1,91,080 \mathrm{MJ} \mathrm{ha}^{-1}\right)$. Establishment methods influenced energy use efficiency significantly. The DSR recorded the maximum value of 8.59 followed by NPTR (7.72) and DSR (6.85). This confirmed that the DSR was more energy efficient than the other establishment methods. Cultivars failed to cause significant variation in total energy input requirement, total energy output, net energy return and energy use efficiency. However, 'Arize 6129' rice hybrid grown in kharif season recorded higher values of energetics indices of post kharif rice-cowpea than other rice cultivars grown in kharif. 
Table 4: Effect of crop establishment methods and cultivar duration of kharif rice on energetics of post kharif rice - cowpea

\begin{tabular}{|c|c|c|c|c|c|c|c|c|}
\hline \multirow{2}{*}{ Particulars } & \multicolumn{2}{|c|}{ Energy input (x 10 ${ }^{3} \mathrm{MJ}$ ha $\left.^{-1}\right)$} & \multicolumn{2}{|c|}{ Energy output $\left(\times 1^{3} \mathrm{MJ} \mathrm{ha}^{-1}\right)$} & \multicolumn{2}{|c|}{ Net energy return $\left(\mathrm{x} \mathrm{10}^{3} \mathrm{MJ} \mathrm{ha}^{-1}\right)$} & \multicolumn{2}{|c|}{ Energy use efficiency } \\
\hline & 2014-15 & 2015-16 & 2014-15 & 2015-16 & 2014-15 & 2015-16 & 2014-15 & 2015-16 \\
\hline \multicolumn{9}{|c|}{ Establishment method } \\
\hline DSR & 25.50 & 25.50 & 219.35 & 216.58 & 193.86 & 191.08 & 8.63 & 8.54 \\
\hline NPTR & 29.24 & 29.62 & 225.20 & 227.26 & 195.96 & 197.64 & 7.73 & 7.71 \\
\hline PTR & 33.07 & 33.06 & 223.64 & 226.45 & 190.58 & 193.39 & 6.78 & 6.91 \\
\hline SEm \pm & 0.32 & 0.31 & 1.05 & 3.53 & 1.29 & 3.68 & 0.13 & 0.15 \\
\hline $\mathrm{CD}(\mathbf{P}=\mathbf{0 . 0 5})$ & 1.27 & 1.22 & 4.13 & NS & NS & NS & 0.50 & 0.58 \\
\hline \multicolumn{9}{|c|}{ Cultivar duration } \\
\hline Arize 6129 & 29.16 & 29.45 & 223.84 & 224.49 & 194.68 & 195.03 & 7.79 & 7.74 \\
\hline Arize 6444 & 29.20 & 29.19 & 222.86 & 222.89 & 193.66 & 193.70 & 7.73 & 7.74 \\
\hline Swarna & 29.45 & 29.53 & 221.50 & 222.92 & 192.06 & 193.38 & 7.63 & 7.67 \\
\hline SEm \pm & 0.68 & 1.02 & 2.18 & 1.67 & 2.65 & 2.30 & 0.23 & 0.29 \\
\hline $\mathrm{CD}(\mathrm{P}=0.05)$ & NS & NS & NS & NS & NS & NS & NS & NS \\
\hline
\end{tabular}

\section{Nutrient uptake}

Establishment methods significantly influenced nitrogen uptake by post kharif crops (Table 5). The NPTR recorded significantly higher nitrogen uptake of $207.6 \mathrm{~kg} \mathrm{ha}^{-1}$ in the $1^{\text {st }}$ year followed by PTR (196.9 $\mathrm{kg} \mathrm{ha}^{-1}$ ) and DSR (178.1 $\mathrm{kg} \mathrm{ha}^{-}$ $\left.{ }^{1}\right)$. However, both NPTR (205.0 kg ha-1) and PTR (200.9 kg $\mathrm{ha}^{-1}$ ) remained at par in the $2^{\text {nd }}$ year and proved significantly superior to DSR (178.3 $\left.\mathrm{kg} \mathrm{ha}^{-1}\right)$. Different establishment methods also influenced phosphorus and potassium uptake significantly. The maximum phosphorus uptake of $38.8 \mathrm{~kg} \mathrm{ha}^{-}$
${ }^{1}$ and potassium uptake of $203.8 \mathrm{~kg} \mathrm{ha}^{-1}$ were recorded under PTR followed by NPTR (37.6 $\mathrm{kg} \mathrm{P} \mathrm{ha}^{-1}$ and $198.1 \mathrm{~kg} \mathrm{~K} \mathrm{ha}^{-1}$ ) and DSR (31.0 kg P ha ${ }^{-1}$ and $173.6 \mathrm{~kg} \mathrm{~K} \mathrm{ha}^{-1}$ ). The minimum uptake of nitrogen, phosphorus and potassium by post kharif rice-cowpea under DSR was due to low total rice equivalent yield. The uptake of nitrogen, phosphorus and potassium was not significantly influenced by the different duration of cultivars grown in kharif. However, 'Arize 6129' recorded higher mean value of nitrogen, phosphorus and potassium uptake by rice-cowpea due to higher yields.

Table 5: Effect of crop establishment methods and cultivar duration of kharif rice on nutrient uptake of post kharif rice - cowpea

\begin{tabular}{|c|c|c|c|c|c|c|}
\hline \multirow{2}{*}{ Particulars } & \multicolumn{2}{|c|}{ Nitrogen uptake (kg grain ha-1) } & \multicolumn{2}{|c|}{ Phosphorus uptake (kg grain ha' ${ }^{-1}$ ) } & \multicolumn{2}{|c|}{ Potassium uptake (kg grain ha ha $^{-1}$ ) } \\
\hline & 1st $^{\text {sear }}$ & $2^{\text {nd }}$ Year & $1^{\text {st }}$ Year & $2^{\text {nd }}$ Year & $1^{\text {st }}$ Year & $2^{\text {nd }}$ Year \\
\hline \multicolumn{7}{|c|}{ Establishment method } \\
\hline DSR & 178.1 & 178.3 & 30.8 & 31.1 & 172.0 & 175.1 \\
\hline NPTR & 207.6 & 205.0 & 37.2 & 37.9 & 198.1 & 198.1 \\
\hline PTR & 196.9 & 200.9 & 37.9 & 39.6 & 202.1 & 205.5 \\
\hline SEm \pm & 2.4 & 3.1 & 0.8 & 0.6 & 2.6 & 3.4 \\
\hline $\mathrm{CD}(\mathrm{P}=\mathbf{0 . 0 5})$ & 9.3 & 12.3 & 3.2 & 2.3 & 10.2 & 13.2 \\
\hline \multicolumn{7}{|c|}{ Cultivar duration } \\
\hline Arize 6129 & 199.3 & 198.3 & 34.4 & 37.0 & 192.1 & 194.1 \\
\hline Arize 6444 & 195.1 & 196.4 & 35.7 & 36.3 & 192.1 & 193.5 \\
\hline Swarna & 188.1 & 189.5 & 35.8 & 35.4 & 188.0 & 191.0 \\
\hline SEm \pm & 3.1 & 3.3 & 0.6 & 0.8 & 2.0 & 3.2 \\
\hline $\mathrm{CD}(\mathbf{P}=0.05)$ & NS & NS & NS & NS & NS & NS \\
\hline
\end{tabular}

\section{Conclusions}

1. Puddled Transplanted Rice recorded the maximum rice equivalent yield (REY) of post kharif crops of $8.43 \mathrm{t} \mathrm{ha}^{-1}$ which was at par with $\operatorname{NPTR}\left(8.34 \mathrm{t} \mathrm{ha}^{-1}\right)$ and the minimum REY was recorded under DSR $\left(6.85 \mathrm{t} \mathrm{ha}^{-1}\right)$.

2. The PTR recorded the maximum gross return of $₹$ 1,20,380/- while net return was the maximum (₹49,310/) under NPTR, But, benefit cost ratio was not significantly affected by establishment methods.

3. The maximum energy input $\left(33,070 \mathrm{MJ} \mathrm{ha}^{-1}\right)$ and output $\left(2,25,045 \mathrm{MJ} \mathrm{ha}^{-1}\right)$ was recorded under the PTR and the NPTR, respectively. But, the DSR(8.59) registered higher energy use efficiency than NPTR and PTR.

4. The NPTR recorded the maximum nitrogen uptake of $206.3 \mathrm{~kg} \mathrm{ha}^{-1}$, while phosphorus (38.8 $\mathrm{kg} \mathrm{ha}^{-1}$ ) and potassium (203.8 $\left.\mathrm{kg} \mathrm{ha}^{-1}\right)$ uptake were the maximum under PTR.

5. The rice cultivar groups grown in kharif failed to cause significant difference in yield, economics, energetics and uptake of nutrient, while 'Arize 6129' recorded higher mean value than cv. Arize 6444 and cv. Swarna.

\section{Acknowledgments}

We acknowledge financial support from USAID funded Cereal Systems Initiative for South Asia (CSISA) project through International Rice Research Institute (IRRI), Philippines. We specially thank the CSISA-Odisha Hub for continuous administrative support and technical assistance for the research. We acknowledge the administrative support provided by OUAT authorities for smooth implementation of the project.

\section{References}

1. Alam MH, Humphreys E, Sarkar MAR, Sudhir-Yadav. Intensification and diversification increase land and water productivity and profitability of rice-based cropping systems on the High Ganges River Floodplain of Bangladesh. Field Crops Research. 2017; 209:10-26.

2. Gangwar B, Ram B. Effect of crop diversification on productivity and profitability of rice (Oryza sativa)-wheat (Triticum aestivum) system. Indian Journal of Agricultural Science. 2005; 75(7):435-438. 
3. Ghosh PK, Mohanty M, Bandyopadhyay KK, Painuli DK, Misra AK. Growth, competition, yields advantage and economics in soybean/pigeonpea intercropping system in semi-arid tropics of India: II. Effect of nutrient management. Field Crops Research. 2006; 96(1):90-97.

4. Mittal JP, Dhawan KC. Research Manual on Energy Requirements in Agricultural Sector. New Delhi: ICAR, 1988.

5. Mukundam B, Yakadri M, Raja V, Srividya S. Diversification of rice (Oryza sativa)-based cropping system for improving productivity and incomein Telangana region of Andhra Pradesh. Indian Journal of Agronomy. 2012; 57(1):20-23.

6. Sarangi SK, Singh S, Virender Kumar, Srivastava AK, Sharma Porbodh C, Johnson David E. Tillage and crop establishment options for enhancing the productivity, profitability, and resource use efficiency of rice-rabi systems of the salt-affected coastal lowlands of eastern India. Field Crops Research. 2020; 247(15):1074-94.

7. Sharma G, Patil SK, Buresh RJ, Mishra VN, Das RO, Haefele SM et al. Rice establishment method affects nitrogen use and crop production of rice-legume systems in drought-prone eastern India. Field Crops Research. 2005; 92(1):17-33.

8. Singh RD, Shivani Khan AR, Chandra N. Sustainable productivity and profitability of diversified rice-based cropping systems in an irrigated ecosystem. Archives of Agronomy and Soil Science. 2012; 58(8):859-869.

9. Singh RD. Food security for increasing rural livelihood under limited water supply through adoption of diversified crops and crop sequences. In: Khan AR, Singh Ss, Bharti RC, Srivastava TK, Khan MA, editors. Resource conservation technologies for food security and rural livelihood. Udaipur (India): Agrotech Publishing Academy. 2010, 342-355. 